\title{
PENYESUAIAN SOSIAL PENYANDANG DISABILITAS TUBUH DI BALAI BESAR REHABILITASI SOSIAL BINA DAKSA (BBRSBD) PROF. DR. SOEHARSO KOTA SURAKARTA, JAWATENGAH
}

\author{
Lukman Prasetyo Utomo \\ Email:Iukman_prazzt@yahoo.com
}

\begin{abstract}
Abstrak:
Final Scientific Writing is based on research about Social Adjustment of Disabled People at Social Rehabilitation House ofBinaDaksa (BBRSBD) of Prof. Dr. Soeharso Surakarta. The objectives of the research are to obtain the description about: the characteristics of respondents and 5 aspects of social adjustment namely: recognition, participation, social approval, altruism, and conformity. The method used in this research was descriptive research method with quantitative approach;it aimed to describe the Social Adjustment of Disabilities People at Social Rehabilitation House of BinaDaksa (BBRSBD) of Prof. Dr. Soeharso Surakarta. Data collection techniques used werequestionnaires, observations, and documentation studies. The research was conducted on 34 respondents determined by census. The results showed that the characteristics of respondents consisted of 10 women and 24 men among the ages of 17-25 years. The result of research also showed that 5 aspects of social adjustment, namely recognition aspect $94,12 \%$ are in high category so that it needs to be maintained, participation aspect $52,94 \%$ is in medium category so that it needs to be improved, social approval aspect $50.00 \%$ is in high category and $50.00 \%$ is in the moderate category so it needs to be improved, altruism aspect $73.53 \%$ is in high category so it needs to be maintained, conformity aspect $85,30 \%$ is in high category so it needs to be maintained. Based on the results of research, the participation and social approval aspects are in the moderate category, so they need to be improved by taking into account the problems faced and the source system that can be utilized, the writer offers problem solving in the form of "Participation Enhancement Program and Social Approval for Disabled People through Self-help Group (selfhelp group) at Social Rehabilitation House of BinaDaksa (BBRSBD) of Prof. Dr. Soeharso Surakarta. ". This program aims to improve the realization of better social adjustment for people with disabilities.
\end{abstract}

Keywords: Social Adjustment, People with Disabilities.

\section{A. Pendahuluan}

Pembangunan nasional bertujuan untuk mewujudkan masyarakat adil dan makmur yang merata, baik material maupun spiritual berdasarkan Pancasila dan UUD 1945. Dalam mewujudkan pembangunan nasional tersebut perlu adanya peran segenap lapisan masyarakat sebagai pelaku 
utama pembangunan, dimana setiap warga negara Indonesia mempunyai kedudukan, hak, kewajiban dan peran yang sama, tak terkecuali bagi penyandang disabilitas. Sehingga pemerintah berkewajiban memberikan perlakuan yang sama kepada para penyandang disabilitas di segala aspek kehidupan.

Jumlah Penyandang Disabilitas cenderung mengalami peningkatan baik secara kualitatif maupun kuantitatif. Berdasarkan data dari Pusdatin Kementerian Sosial RI tahun 2009 jumlah penyandang disabilitas di Indonesia sebanyak 1.541.942 jiwa dan mengalami peningkatan pada tahun 2011 sebanyak 2.126.785 jiwa. Penyandang Disabilitas Tubuh atau Tunadaksa menempati urutan pertama yaitu 717.312 jiwa atau sekitar $33,74 \%$ dari semua penyandang disabilitas yang ada di Indonesia. Menurut data Pusdatin Kementerian Sosial RI tahun 2011 Provinsi Jawa Barat Penyandang Disabilitas Tubuh berjumlah 152.283 jiwa dan Provinsi Jawa Timur Penyandang Disabilitas berjumlah 382.772 jiwa. Provinsi yang mempunyai Penyandang Disabilitas Tubuh lebih tinggi yaitu di Jawa Tengah yaitu sebesar 383.343 jiwa. Sehingga dengan jumlah yang cukup besar ini menjadi tugas bagi pemerintah dan semua elemen masyarakat untuk peduli terhadap penyandangdisabilitas.

Penanganan penyandang disabilitas tubuh merupakan salah satu bentuk pembangunan kesejahteraan sosial di Indonesia, maka dari itu dirasakan penting untuk penanganan penyandang disabilitas di Indonesia. Hal tersebut sangat relevan dengan kebijakan pemerintah dalam UndangUndang Nomor 19 Tahun 2011 tentang Pengesahan Konvensi Mengenai Hak-hak Penyandang Disabilitas. Sehingga peningkatan pelayanan kesejahteraan sosial bagi penyandang disabilitas merupakan perwujudan atas hak-hak mereka sebagai warga negara, di mana mereka juga memiliki hak untuk mendapatkan pelayanan sosial seperti: rehabilitasi, pemberian 
bantuan sosial dan pemeliharaan taraf kesejahteraan sosial, yang semuanya menjadi tanggung jawab bersama antara Pemerintah, masyarakat, keluarga serta penyandang disabilitas itu sendiri.

Konsep Penyandang Disabilitas ditinjau dari Undang-Undang Nomor 4 Tahun 1997 tentang Penyandang Cacat pasal 1 ayat (1), yang menegaskan bahwa penyandang cacat adalah "Setiap orang yang mempunyai kelainan fisik dan atau mental, yang dapat mengganggu atau merupakan rintangan dan hambatan baginya untuk melakukan secara layaknya yang terdiri dari penyandang cacat fisik, penyandang cacat mental, penyandang cacat fisik dan mental."

Sementara konsep disabilitas menurut World Health Organization (WHO) sebagaimana dikutip Departemen Sosial RI (2008:7) dalam buku Panduan Kriteria Penyandang Cacat Fisik, Disability: a limitation in expected functional due to an underlying impairment; a restriction or lack of ability to perform an activity within the range considered normal for human being. This restriction or lack of ability is often soscially created. Pengertian tersebut, disability dikatakan sebagai suatu keterbatasan atau kehilangan kemampuan untuk melakukan suatu kegiatan dengan cara atau dalam batas-batas yang dipandang normal sebagai seorang manusia.

Hal ini sebagai suatu ketidakmampuan melaksanakan suatu aktivitas/kegiatan tertentu sebagaimana layaknya orang normal yang disebabkan oleh kondisi impairment yang berhubungan dengan usia dan masyarakat dimana seseorang berada.

Pada dasarnya, Penyandang Disabilitas Tubuh mempunyai kebutuhan sama dengan individu normal akan tetapi karena kekurangan yang ada pada fisiknya membuat mereka menemukan banyak kesulitan. Mereka dituntut untuk mampu menghadapi tantangan atau persaingan hidup sama seperti manusia normal lainnya. Penyandang disabilitas tubuh 
tentu saja mengalami kesulitan dalam kehidupan pribadi, keluarga dan masyarakat yang disebabkan ketidaknormalan tulang dan otot sehingga tidak mampu menjalankan fungsi sosialnya secara wajar. Atau lebih jelasnya mereka mengalami hambatan dalam melaksanakan aktivitasnya sehari-hari seperti hambatan fisik, mobilitas, mental psikologis, produktivitas kerja serta hambatan dalam melaksanakan fungsi sosialnya.

Dalam berbagai kasus di masyarakat yang ada masih terdapat hambatan untuk para penyandang disabilitas tubuh yang mengalami dalam masalah mengembangkan kemampuan dan penyesuaian sosialnya. Adapun kesulitan tersebut disebabkan oleh keterbatasan kemampuan, pengetahuan, keterampilan, pendidikan, dan rendahnya penilaian masyarakat terhadap kemampuan dan potensi yang dimiliki oleh para penyandang disabilitas tubuh sehingga menyebabkan kurang percaya diri, minder dan merasa tidak berguna (Lauster, 2006).

Upaya pemerintah untuk meningkatkan kesejahteraan sosial penyandang disabilitas salah stunya dengan adanya rehabilitasi bagi penyandang disabilitas. Balai rehabilitasi bagi penyandang disabilitas tersebut difungsikan untuk membantu para penyandang disabilitas yang ada di Indonesia untuk memperbaiki keberfungsiannya kembali dan mengembangkan kemampuan fisik, mental dan sosial penyandang disabilitas agar bisa berfungsi sosial secara wajar kembali sesuai bakat, kemampuan, pendidikan dan pengalamannya. Salah satu unit pelaksana teknis atau tempat rehabilitasi yang dimiliki pemerintah yaitu Balai Besar Rehabilitasi Sosial Bina Daksa (BBRSBD) Prof. Dr. Soeharso yang berada di Surakarta. Di balai tersebut, penyandang disabilitas tubuh atau tuna daksa mendapatkan pelayanan rehabilitasi sosial. Dari pelayanan itu para penyandang disabilitas tubuh bisa mengasah kemampuan, bakat, keterampilan dan mendapatkan pengalaman yang nantinya akan 
menjadikan mereka bisa berfungsi sosial kembali apabila sudah kembali ke masyarakat.

Manusia sebagai makhluk sosial selalu berinteraksi dan membutuhkan orang lain dalam kehidupannya. Oleh karena itu setiap individu membutuhkan keterampilan sosial untuk membangun sebuah hubungan yang harmonis dengan individu yang lain. Schneirders dalam Hurlock (2002) mengatakan penyesuaian sosial merupakan proses mental dan tingkah laku yang mendorong seseorang untuk menyesuaikan diri dengan keinginan yang berasal dari dalam diri sendiri yang dapat diterima oleh lingkungannya. Individu dianggap memiliki penyesuaian sosial yang baik, jika perilaku individu tersebut mencerminkan keberhasilan dalam proses sosialisasi sehingga cocok dengan tempat mereka menggabungkan diri dan diterima sebagai anggota kelompok maupun anggota masyarakat.

Secara umum penyesuaian sosial merupakan sesuatu yang lazim dialami seseorang ketika memasuki suatu lingkungan yang baru tak terkecuali bagi penyandang disabilitas tubuh di BBRSBD Prof. Dr. Soeharso ini. Namun,penyesuaian sosial akan menjadi suatu masalah ketika seseorang tidak bisa menyesuaikan diri untuk menjadi bagian dalam lingkungan baru tersebut atau karena ia tidak mampu mempelajari hal-hal yang ada di lingkungan sosialnya tersebut. Jika masalah-masalah penyesuaian sosial tersebut tidak segera diatasi dapat menimbulkan hambatan-hambatan dalam mengikuti setiap kegiatan yang diadakan oleh pihak balai tersebut. Apabila hal tersebut dibiarkan, dapat menimbulkan ketidakmampuan klien penyandang disabilitas tubuh dalam melaksanakan kehidupannya secara wajar jika nanti kembali ke masyarakat.

Dalam perkembangannya, Penyandang Disabilitas Tubuh besar kemungkinan akan mengalami kesulitan dalam penyesuaian dengan lingkungan sosialnya. Hal ini berkaitan erat dengan perlakuan masyarakat 
terhadap penyandang disabilitas tubuh. Seperti ejekan dan gangguan dari anak-anak normal yang mengakibatkan timbulnya perasaan negatif pada diri mereka terhadap lingkungan sosialnya, keadaan ini menyebabkan hambatan pergaulan sosial penyandang disabilitas tubuh (Sutjihati Somantri, 2007).

Pentingnya penyesuaian sosial bagi Penyandang Disabilitas Tubuh agarmereka dapat menjalani dengan baik program rehabilitasi yang diberikan oleh pihak balai guna mengasah kemampuan, bakat, keterampilan dan mendapatkan pengalaman yang nantinya akan menjadikan mereka bisa berfungsi sosial kembali apabila sudah kembali ke masyarakat.

Berdasarkan fenomena tersebut menunjukkan bahwa penyesuaian sosial penyandang disabilitas tubuh merupakan permasalahan yang menarik untuk dikaji lebih lanjut. Untuk itulah penelitian ini dilakukan untuk mengetahui bagaimanakah Penyesuaian Sosial Penyandang Disabilitas Tubuh di BBRSBD Prof. Dr. Soeharso Surakarta Jawa Tengah

Berdasarkan konteks penelitian di atas maka yang menjadi fokus penelitian dalam penelitian ini adalah"bagaimanakah Penyesuaian Sosial Penyandang Disabilitas Tubuh di Balai Besar Rehabilitasi Sosial Bina Daksa Prof. Dr. Soeharso Surakarta, Jawa Tengah". Selanjutnya fokus masalah penelitian ini dirinci pada sub-sub permasalahan sebagai berikut : (1) Bagaimanakah karakteristik responden? (2) Bagaimanakah recognition responden? (3) Bagaimanakah participation responden? (4) Bagaimanakah social approval responden? (5) Bagaimanakah altruisme responden? (6) Bagaimanakah conformity responden?

\section{B. Metode Penelitian}

Pendekatan yang digunakan dalam penelitian ini adalah pendekatan kuantitatif dengan metode deskriptif. Penelitian kuantitatif adalah metode 
penelitian untuk meneliti populasi atau sampel tertentu, pengumpulan data menggunakan instrumen penelitian, analisis data bersifat kuantitatif atau statistik, dengan tujuan untuk menguji hipotesis yang telah ditetapkan (Sugiyono,2012). Pendekatan kuantitatif digunakan untuk meneliti permasalahan penyesuaian sosial penyandang disabilitas tubuh di Balai Besar Rehabilitasi Sosial Bina Daksa (BBRSBD) Prof. Dr. Soeharso Surakarta.

Metode deskriptif adalah suatu metode dalam penelitian status kelompok manusia, suatu obyek, suatu set kondisi, suatu sistem pemikiran ataupun suatu kelas peristiwa pada masa sekarang. Tujuan penelitian deskriptif adalah untuk membuat deskriptif, gambaran atau lukisan secara sistematis, faktual dan akurat mengenai fakta-fakta, sifat-sifat serta hubungan antar fenomena yang diselidiki (Moh. Nazir, 1999: 63).

Metode deskriptif ini digunakan untuk memperoleh gambaran secara jelas mengenai permasalahan yang berkaitan dengan penyesuaian sosial penyandang disabilitas tubuh di Balai Besar Rehabilitasi Sosial Bina Daksa Prof. Dr. Soeharso Surakarta, Jawa Tengah.

Teknik pengumpulan data yang di gunakan adalah kuisioner, observasi, dan dokumentasi. Untuk teknik analisis data adalah menyederhanakan data kedalam bentuk yang lebih mudah dibaca dan dipresentasikan. Teknik analisis data yang digunakandalam penelitian ini adalah teknik analisis data statistik deskriptif. Menurut Sugiyono (2012) statistik deskriptif adalah: "statistik yang digunakan untuk menganalisa data dengan cara mendeskripsikan atau menggambarkan data yang terkumpul sebagaimana adanya tanpa bermaksud membuat kesimpulan yang berlaku untuk umum atau generalisasi".

Dalam penelitian ini hasil penelitian diolah dengan menggunakan analisis data kuantitatif. Analisis kuantitatif yaitu menganalisis data secara rinci dalam bentuk angka atau persentase dari jawaban responden atas 
pertanyaan penelitian untuk mendapatkan deskripsi tentang masalah penelitian. Data disajikan dalam bentuk tabel, grafik sederhana dengan distribusi frekuensi.

Hasil yang diperoleh dari pengumpulan data melalui kuesioner akan dihitungsehingga mendapatkan hasil yang dapat dipresentasikan dalam bentuk grafik dari tabel data. Rentang skor dalam penyajian tabel frekuensi diperoleh dengan cara : (1) Terlebih dahulu mencari nilai tertinggi (skor jawaban terbesar dikali banyaknya item) (2) Mencari nilai terendah (skor jawaban terendah dikali banyaknya item)(3) Mencari range (nilai tertinggi dikurangi nilai terendah kemudian dibagi dengan banyaknya kategori).

Dalam pengujian validitas dan realibilitas alat ukur dimaksudkan untuk mengetahui apakah alat ukur yang digunakan dalam penelitian ini dapat mengukur variabel penelitian. Validitas alat ukur yang digunakan adalah validitas muka, yaitu melakukan konsultasi dengan pihak terkait yang ahli dalam masalah validitas alat ukur, dalam hal ini adalah dosen pembimbing penelitian.

\section{Hasil dan Pembahasan}

Penelitian tentang penyesuaian sosial penyandang disabilitas tubuh di BBRSBD Prof. Dr. Soeharso dilakukan pada responden yang berusia 17-25 tahun. Penyesuaian sosial adalah proses mengubah diri yang dilakukan oleh penyandang disabilitas tubuh yang terdiri aspek recognition (menghormati dan menerima hak-hak orang lain), participation (melibatkan diri dalam berelasi), social approval (minat dan simpati terhadap kesejahteraan orang lain), altruisme (memiliki sifat rendah diri dan tidak egois), dan conformity (menghormati dan mentaati nilai-nilai integritas hukum, tradisi, dan kebiasaan) di BBRSBD Prof. Dr. Soeharso Surakarta. Dari hasil analisis masalah yang diperoleh dari penelitian ini menunjukkan bahwa masing- 
masing responden memiliki tingkat penyesuaian sosial yang berbeda-beda. Hal ini dapat dilihat melalui kuesioner yang telah diajukan oleh peneliti terhadap 34 responden yang berkaitan dengan penyesuaian sosial responden di Balai Besar Rehabilitasi Sosial Bina Daksa "Prof. Dr. Soeharso", Surakarta. Adapun hasil penelitian dan analisis masalah tentanggambaran penyesuaian sosial penyandang disabilitas tubuh di BBRSBD Prof. Dr. Soeharso Surakarta adalah sebagai berikut

1. Karakteristik Responden

Menurut hasil penelitian yang dilakukan, karakteristik responden menurut usia sebagian besar responden berusia 19-24 tahun atau berada pada masa dewasa dini. Merujuk pendapat Hurlock (1980) masa dewasa dini merupakan periode penyesuaian diri terhadap pola-pola kehidupan baru dan harapan-harapan sosial baru, periode ini sangat sulit sebab sebagai orang dewasa, mereka diharapkan mengadakan penyesuaian diri secara mandiri. Hal ini menunjukkan apabila mereka menemui kesulitan yang sukar diatasi, mereka ragu-ragu untuk minta pertolongan dan nasihat orang lain karena enggan kalau dianggap belum dewasa. Sedangkan dilihat dari tingkat pendidikan sebagian besar responden berlatar pendidikan SD. Hal ini menunjukkan untuk tolak ukur pendidikan masyarakat kota, dapat dinilai tingkat pendidikan responden masih rendah. Hal ini berpengaruh terhadap pola pikir dan bentuk proses penyesuaian sosial responden. Karakteristik responden menurut agama menjelaskan bahwa hampir semua beragama Islam. Hal ini dapat mempermudah dalam melakukan pendekatan agama terhadap responden karena di Kota Surakarta juga sebagian besar beragama Islam. Pendekatan agama dilakukan agar responden sadar dan dapat memperbaiki perilaku sehingga proses adaptasi akan terbentuk melalui pendekatan agama tersebut.

2. Aspek Recognition Responden 
Penyesuaian sosial dalam aspek recognition mengacu pada kecenderungan penyandang disabilitas tubuh atau responden di BBRSBD Prof. Dr. Soeharso Surakarta dalam hal menghormati dan menerima hakhak orang lain. Menurut Schneiders dalam bukunya "Personal Adjustment and Mental Health" (1964: 454), ketika kita dapat menghargai dan menghormati hak-hak orang lain maka orang lain akan menghormati dan menghargai hak-hak kita sehingga hubungan sosial antar individu dapat terjalin dengan sehat dan harmonis. Artinya, individu yang kurang menghormati dan menerima hak-hak orang lain akan berdampak terjadinya konflik sosial sehingga hubungan sosial antar individu kurang terjalin dengan sehat dan harmonis pula serta kurang diterimanya individu tersebut dalam lingkungan dimana ia tinggal.

Berdasarkan hasil penelitian pada aspek recognition, sebagian besar responden berada pada kategori tinggi dan hanya 2 responden yang berada pada kategori sedang, dimana mengalami permasalahan terutama dalam hal menyapa orang lain yang hanya dikenal saja. Hal ini terjadi karena adanya ketidakpahaman responden terhadap penghormatan terhadap hak orang lain yaitu salah satunya sapaan tidak hanya terhadap orang yang dikenal saja melainkan kepada orang lain pun yang tidak dikenal juga. Sebagai akibatnya responden selamamenjalani proses rehabilitasi akan membentuk proses penyesuaian sosial yang kurang baik.

\section{Aspek Participation responden}

Penyesuaian sosial dalam aspek participation mengacu pada kecenderungan penyandang disabilitas tubuh atau responden di BBRSBD Prof. Dr. Soeharso Surakarta dalam hal melibatkan diri dalam berelasi. Menurut Schneiders dalam bukunya "Personal Adjustment and Mental Health" (1964 : 454), individu yang mampu menciptakan relasi yang sehat dengan orang lain, mengembangkan persahabatan, berperan aktif dalam 
kegiatan sosial, serta menghargai nilai-nilai yang berlaku di lingkungannya akan membentuk penyesuaian yang baik. Artinya, individu yang tidak mampu membangun relasi dengan orang lain dan lebih menutup diri dari relasi sosial akan menghasilkan penyesuain diri yang buruk. Individu ini tidak memiliki ketertarikan untuk berpartisipasi dengan aktivitas dilingkungannya serta tidak mampu untuk mengekspresikan diri mereka sendiri.

Berdasarkan hasil penelitian pada aspek participation, sebagian responden berada pada kategori tinggi tetapi sebagian besar sejumlah18 responden berada pada kategori sedang, dimana mengalami permasalahan terutama dalam hal berbicara hanya dengan orang yang dikenal saja, berkumpul hanya dengan orang yang dikenal saja, kurang senang menonton tv dengan teman yang lain, tidak senang dilibatkan dalam kegiatan apapun. Hal tersebut apabila dibiarkan tidak segera ditangani akan rentan menjadi kategori rendah.

Hal ini terjadi karena kekurangmampuan responden dalam melibatkan diri dalam berelasi dengan kaitan penyesuaian sosial. Komunikasi adalah hal yang sangat diperlukan ketika responden hidup secara kelompok. Dengan berkomunikasi atau berbicara dengan orang lain, responden dapat memahami karakteristik masing-masing individu, sehingga dengan mudah responden dapat bersosialisasi dengan orang lain. Inilah merupakan salah satu bentuk penyesuaian sosial. Selain itu, dengan kominikasi yang terjalin baik dengan orang lain terutama dengan teman sesama penerima manfaat akan membentuk solidaritas yang kuat dan rasa saling menghargai sehingga memudahkan responden untuk diterima dalam bergaul dengan orang lain. Hal positif ini seharusnya dijadikan motivasi bagi responden untuk serius dalam menjalani proses rehabilitasi di balai agar ketika responden kembali ke masyarakat nantinya 
memberikan nilai postif dari masyarakat dan mendapatkan sesuatu yang bermanfaat bagi dirinya sendiri. Bukan justru sebaliknya dimana responden kurang bisa mengekspresikan dirinya dalam hal berelasi dengan orang lain yang mengakibatkan selama menjalani proses rehabilitasi akan membentuk proses penyesuaian sosial yang kurang baik sehingga berdampak kurang baik pula terhadap dirinya sendiri ketika nanti kembali ke masyarakat.

4. Aspek Social Approval

Penyesuaian Sosial dalam aspek Social Approval mengacu pada kecenderungan penyandang disabilitas tubuh atau responden di BBRSBD Prof. Dr. Soeharso Surakarta dalam hal minat dan simpati terhadap kesejahteraan orang lain. Menurut Schneiders dalam bukunya "Personal Adjustment and Mental Health" (1964 : 454), individu yang dapat menunjukkan minat dan simpati terhadap kesejahteraan orang lain akan menciptakan kenyamanan dalam berhubungan dengan orang lain sehingga penyesuaian akan terbentuk dengan baik. Artinya, individu yang kurang dapat menunjukkan minat dan simpati terhadap kesejahteraan orang lain akan menciptakan kekurangnyamanan terhadap orang lain dalam hal hubungan sosial dan membentuk penyesuaian yang kurang baik pula.

Berdasarkan hasil penelitian pada aspek social approval, sebanyak 17 responden atau $50 \%$ berada pada kategori tinggi dan $50 \%$ responden berada pada kategori sedang, dimana mengalami permasalahan terutama dalam hal menasihati orang lain apabila melakukan kesalahan, menghibur orang lain yang sedang mempunyai masalah, membantu orang lain mencarikan jalan keluar apabila sedang mempunyai masalah. Hal ini apabila dibiarkan akan memungkinkan berkurangnya kategori tinggi dan bertambahnya menjadi kategori sedang bahkan menjadi kategori rendah. 
Hal ini terjadi karena kurang adanya kepekaan responden terhadap kesejahteraan orang lain dalam hal meringankan masalah yang dihadapi orang lain. Selain itu, akan membentuk sifat egois dan akan membuat kurang nyaman dalam hubungan sosial dengan orang lain sehingga membentuk penyesuaian sosial yang kurang baik pula. Sebaliknya apabila responden dapat menunjukkan minat dan simpati terhadap orang lain maka akan membentuk penyesuaian sosial yang baik. Hal ini dapat merupakan bentuk penyesuaian diri dimasyarakat, dimana individu yang peka dengan masalah dan kesulitan orang lain disekelilingnya serta bersedia membantu meringankan masalahnya akan mudah diterima di lingkungannya.

5. Aspek Altruisme Responden

Penyesuaian sosial dalam aspek altruisme mengacu pada kecenderungan penyandang disabilitas tubuh atau responden di BBRSBD Prof. Dr. Soeharso Surakarta dalam hal memiliki sifat rendah hati dan tidak egois. Menurut Schneiders dalam bukunya "Personal Adjustment and Mental Health" (1964 : 454), individu yang memiliki sifat rendah diri dan tidak egois akan memiliki kestabilan mental, keadaan emosi yang sehat dan penyesuaian yang baik. Artinya, individu yang kurang memiliki sifat rendah diri dan tidak egois akanmemiliki ketidakstabilan mental dan emosi serta penyesuaian yang kurang baik pula.

Berdasarkan hasil penelitian pada aspek altruisme, sebagian besar responden barada pada kategori tinggi dan ada 9 orang responden berada pada kategori sedang, dimana mengalami permasalahan terutama dalam hal memaksakan kehendak orang lain untuk mengikuti keinginannya dan lebih mendahulukan kepentingan orang lain daripada diri sendiri. Hal ini terjadi karena responden kurang memiliki sifat rendah dengan memiliki rasa saling membantu dan mementingkan orang lain merupakan nilai-nilai 
moral yang aplikasi dari nilai-nilai tersebut merupakan bagian dari penyesuaian moral yang baik yang apabila diterapkan dimasyarakat secara wajar dan bermanfaat maka akan membawa pada penyesuaian diri yang kuat. Selain itu, akan terhindar dengan konflik sosial, tercipta kenyamanan dalam berhubungan secara sosial dengan orang lain, membuat konsep diri yang positif, dan dapat mudah diterima oleh lingkungannya.

6. Aspek Comformity Responden

Penyesuaian sosial dalam aspek comformity mengacu pada kecenderungan penyandang disabilitas tubuh atau responden di BBRSBD Prof. Dr. Soeharso Surakarta dalam hal menghormati dan mentaati nilainilai integritas hukum, tradisi dan kebiasaan. Menurut Schneiders dalam bukunya "Personal Adjustment and Mental Health" (1964 : 454), Dengan adanya kesadaran untuk mematuhi dan menghormati peraturan dan tradisi yang berlaku dilingkungan maka individu akan dapat diterima dengan baik dilingkungannya. Artinya, individu yang kurang memiliki kesadaran untuk mematuhi dan menghormati peraturan dan tradisi yang ada di lingkungannya akankurang diterima baik di lingkungannya pula.

Berdasarkan hasil penelitian pada aspek comformity, sebagian besar berada pada kategori tinggi tetapi ada 5 responden yang berada pada kategori sedang, dimana mengalami permasalahan terutama dalam hal mengikuti kegiatan kesenian, kegiatan olahraga, melaksanakan Orientasi Mobilitas, melaksanakan pelatihan ADL, dan tepat waktu mengikuti kegiatan yang ada. Hal tersebut terjadi karena kurangnya kesadaran beberapa responden tentang menghormati dan menaati peraturan yang ada di lingkungan dimana ia tinggal. Kurang adanya kesadaran responden adalah salah satu indikasi tidak tercapainya penyesuaian sosial. Kurang adanya kesadaran tersebut yang menghambat responden untuk dapat merubah perilaku sesuai dengan norma-norma yang berlaku di 
masyarakat, agar dapat menyesuaikan diri dengan lingkungan tersebut. Selain itu, kedisiplinan waktu dalam mengikuti kegiatan yang ada dapat menggali dan mengembangkan bakat atau potensi yang dimiliki bagi responden serta merupakan kunci keberhasilan dalam pelayanan rehabilitasi di balai.

\section{Kesimpulan}

Penyesuaian sosial Penyandang Disabilitas Tubuh dalam lembaga pelayanan rehabilitasi akan sangat berbeda dengan Penyandang Disabilitas Tubuh yang berada dalam lingkungan keluarga ataupun masyarakat. Banyaknya jumlah penerima manfaat akan membuat penyesuaian sosial Penyandang Disabilitas Tubuh semakin sulit dengan kebutuhan dan permasalahan individu yang berbeda-beda. Individu atau dalam hal ini Penyandang Disabilitas Tubuh harus dapat menyesuaikan diri dengan tuntutan aturan yang berlaku dan puluhan bahkan ratusan Penyandang Disabilitas Tubuh yang berstatus penerima manfaat dan hal tersebut merupakan hal yang sangat tidak mudah.

Melihat hal tersebut maka peneliti tertarik melakukan penelitian tentang penyesuaian sosial penyandang disabilitas tubuh di Balai Besar RehabilitasiSosial Bina Daksa (BBRSBD) Prof. Dr. Soeharso Surakarta. Balai tersebutmemiliki penerima manfaat yang tinggal di balai sejumlah 117 jiwa dan mendapatkan pelayanan berbasis institusi. Peneliti menentukan kriteria dalam memilih sampel yang akan menjadi responden dalam penelitian yaitu penerima manfaat laki-laki dan perempuan yang berusia 17-25 tahun yang bisa baca tulis.

Berdasarkan hasil penelitian tentang Penyesuaian Sosial Penyandang Disabilitas Tubuh di Balai Besar Rehabilitasi Sosial Bina Daksa Prof. Dr. Soeharso Surakarta, Jawa Tengah dapat diketahui masalah yang dihadapi adalah sebagai berikut. 
1. Karakteristik responden

Menurut hasil penelitian yang dilakukan, karakteristik responden berdasarkan tingkat pendidikan, sebagian besar responden berlatar pendidikan SD. Hal ini menunjukkan untuk tolak ukur pendidikan masyarakat kota, dapat dinilai tingkat pendidikan responden masih rendah. Hal ini berpengaruh terhadap pola pikir dan bentuk proses penyesuaian sosial responden.

2. Aspek recognition responden

Menurut hasil penelitian, sebagian besar proses penyesuaian sosial aspek recognition responden berada pada katagori tinggi. Proses penyesuaian sosial aspek recognition terbentuk dari responden dalam menghormati dan menerima hak-hak orang lain. Tetapi beberapa responden masih belum memahami hal tersebut yaitu dalam hal hanya menyapa orang yang dikenal saja sehingga menghambat proses penyesuian sosial responden.

3. Aspek participation responden

Menurut hasil penelitian, dapat disimpulkan bahwa sebagian besar penyesuaian sosial aspek particition responden berada pada katagori sedang, karena sebagian besar mengalami hambatan terutama dalam hal berbicara dengan orang yang tidak hanya dikenal saja, berkumpul dengan orang yang tidak hanya dikenal saja, lebih senang nonton tv bareng teman yang lain, dan lebih senang dilibatkan dalam kegiatan apapun yang mana hal tersebut adalah bentuk-bentuk dari penyesuaian sosial.

4. Aspek social approval responden

Menurut hasil penelitian, dapat disimpulkan bahwa sebagian besar penyesuaian sosial aspek social approval responden pada katagori sedang. Di mana setengah responden atau 50\% mengalami hambatan terutamadalam hal menasihati orang lain apabila melakukan kesalahan, 
menghiburorang lain yang sedang mempunyai masalah, dan membantu orang lain mencarikan jalan keluar apabila sedang mempunyai masalah.

5. Aspek altruisme responden

Menurut hasil penelitian, dapat disimpulkan bahwa sebagian besar penyesuaian sosial aspek altruisme responden pada kategori tinggi. Di mana sebagian besar responden sudah berhasil melakukannya. Namun, sebagian responden mengalami hambatan dalam hal tidak memaksakan kehendak orang lain untuk mengikuti keiinginannya dan lebih mementingkan kepentingan orang lain daripada diri sendiri.

6. Aspek comformity responden

Menurut hasil penelitian, dapat disimpulkan bahwa sebagian besar penyesuaian sosial aspek comformity responden pada kategori tinggi. Di mana sebagian besar responden sudah berhasil melakukannya. Namun, sebagian responden mengalami hambatan dalam mengikuti kegiatan kesenian, mengikuti kegiatan olahraga, melaksanakan Orientasi Mobilitas (OM), melaksanakan pelatihan Activity of Daily Living ( $A D L)$, dan tepat waktu mengikuti kegiatan yang ada .

Hasil penelitian tersebut menunjukkan bahwa muncul beberapa aspek penyesuaian sosial yang masih dapat ditingkatkan lebih baik lagi. Aspek tersebut adalah participation dan social approval. Aspek tersebut menghasilkan angka prosentase pada kategori yang berada paling rendah diantara tiga aspek penyesuaian sosial lainnya serta masih banyak responden yang berada pada kategori sedang dalam aspek tersebut. Sehingga penyesuaian sosial aspek ini lebih diprioritaskan dalam pemecahan masalah.

Melihat penyesuaian sosial yang masih dapat ditingkatkan lagi maka peneliti merancang sebuah program yang bertujuan untuk meningkatkan penyesuaian sosial aspek participation dan social approval. Program 
tersebut berupa diskusi dan sharing yang mengarah pada pemecahan atau solusi masalah yang dihadapi yang nantinya selain akan menambah pengetahuan dari penerima manfaat juga akan menjadi ajang bagi penerima manfaat untuk mengekspresikan diri.

Program yang ditawarkan pada balai adalah Program Peningkatan Participation dan Social Approval Penyandang Disabilitas Tubuh Melalui Kelompok Bantu Diri. Program tersebut meggunakan metode social group work karena metode tersebut sangat cocok digunakan pada suatu kelompok dalam hal ini adalah penerima manfaat yang nantinya dikelompokkan sesuai dengan hambatan dan permasalahan yang dimiliki. Jenis kelompok yang dipakai adalah kelompok bantu diri. Kelompok bantu diri ini dipilih karena selain akan meningkatkan penyesuaian sosial yang dimiliki oleh penerima manfaat juga merupakan sarana untuk menyelesaikan hambatan dan permasalahan bagi penyandang disabilitas tubuh yang merasa senasib sehingga terbentuk partisipasi serta minat dan simpati terhadap kesejahteraan orang lain. Selain itu, dengan adanya program ini diharapkan dapat memberikan kesempatan kepada penerima manfaat untuk menunjukkan kesolidaritasan dan kemampuan yang dimiliki oleh mereka.

\section{Daftar Pustaka}

Hurlock, B. Elizabeth, (2002), Alih Bahasa : Med Meitasari T dan Muslichah Z., Perkembangan Anak Jilid I, Erlangga, Jakarta. (1980), Psikologi Perkembangan Suatu Pendekatan Sepanjang

Rentang Kehidupan, PT. Erlangga, Jakarta.

Lauster, P. (2006), Tes Kepribadian, Jakarta.

Moh. Nazir, (1999), Metode Penelitian, Ghalia Indonesia, Jakarta. 
Lukman Prasetyo. U

Schneiders, A. (1964), Personal Adjustment and Mental Health. New York : Rinehart and Winston.

Sugiyono, (2012), Metode Penelitian Kuantitatif Kualitatif dan R\&D, Alfabeta, Bandung.

T. Sutjihati Soemantri, (2007), Psikologi Anak Luar Biasa, PT. Refika Aditama, Bandung.

Sumber Lain:

Departemen Sosial RI, (2008), Panduan Kriteria Penyandang Cacat Fisik, Ditjen Pelayanan dan Rehabilitasi Sosial Kementerian Sosial RI, Jakarta. Kementerian Sosial RI (2009), Data Penyandang Masalah Kesejahteraan Sosial dan Potensi dan Sumber Kesejahteraan Sosial, Pusdatin, Jakarta. (2011), Data Penyandang Masalah Kesejahteraan Sosial dan Potensi dan Sumber Kesejahteraan Sosial, Pusdatin, Jakarta.

Undang-Undang No. 4 Tahun 1997 Tentang Penyandang Cacat Pasal 1 ayat (1).

Undang-Undang No. 19 Tahun 2011 Tentang Konvensi Hak Penyandang Disabilitas 